\title{
ANALISIS FRAMING DALAM RISET PUBLIC RELATIONS
}

\author{
Narayana Mahendra Prastya \\ Program Studi Ilmu Komunikasi, Fakultas Psikologi dan Ilmu Sosial Budaya, \\ Universitas Islam Indonesia (UII) Yogyakarta \\ nara.prastya@gmail.com
}

\begin{abstract}
This paper aims to give description about how to use frame analysis in Public Relations $(P R)$ research. The author use two framing models: Entman and Pan E Kosicki. The object is organization official statement about particular issue. Frame analysis method rarely used in Public Relations research. This methods commonly use in journalism study, to analyse the news in media. Meanwhile, the key word of framing is the social construction of reality. Organization can make social construction of realty in their official statement. In acacemic term, frame analysis in PR research is useful to know how organization positioned themselves in particular situation. Other benefit is use to evaluat whether the organization frame is conformable with the public opinion or agenda setting media or not. In practical term, frame analysis give benefit for PR practitioner to create the message that can be undserstood by public, also give positive image for organization.
\end{abstract}

Keywords: Frame Analysis, Social Construction of Reality, Public Relations Research

\begin{abstract}
Abstrak
Tulisan ini bermaksud memberikan gambaran tentang bagaimana melakukan penelitian menggunakan analisis framing terhadap teks pernyataan resmi organisasi. Model framing yang dipilih sebagai contoh adalah model Entman dan Pan E Kosicki. Metode analisis framing masih jarang digunakan dalam penelitian di bidang Public Relations (PR). Metode ini memang lebih umum digunakan dalam bidang jurnalistik, yakni menganalisis isi pemberitaan media. Kata kunci framing adalah konstruksi realitas sosial. Organisasi juga dapat melakukan konstruksi realitas melalui pernyataan resmi yang disampaikan. Secara akademis, manfaat pertama analisis framing dalam penelitian $P R$ berguna untuk mengetahui bagaimana organisasi memposisikan diri dalam sebuah situasi tertentu. Manfaat kedua adalah untuk mengevaluasi apakah pesan yang disampaikan oleh organisasi sudah sesuai atau belum dengan agenda setting media dan/atau opini publik. Secara praktis, framing bermanfaat bagi PR organisasi untuk menyusun pesan yang dapat diterima oleh publik dan menghadirkan citra positif bagi organisasi.
\end{abstract}

Kata Kunci : Analisis Framing, Konstruksi Realitas Sosial, Penelitian Public Relations 


\section{PENDAHULUAN}

Penelitian menggunakan analisis teks dalam bidang Public Relations (PR) masih jarang dilakukan. Secara umum, menurut Schulz, et.al. (2011), penelitian bidang PR sejauh ini masih didominasi dengan perspektif yang berpusat pada organisasi dan perspektif bagaimana publik merespon program-program PR. Penelitian bidang PR baru mengkaji bagaimana keterkaitan antara strategi komunikasi perusahaan, pemberitaan media mengenai organisasi, dan persepsi publik terhadap pesan yang disampaikan organisasi.

Penggunaananalisisteksdalampenelitian bidang PR lebih cenderung bertujuan mengukur teks secara kuantitatif, untuk mengetahui bagaimana citra perusahaan. Padahal metode analisis teks tidak hanya secara kuantitatif. Salah satu bentuk analisis teks yang jarang digunakan dalam penelitian PR adalah analisis framing. Hal ini wajar, karena pada umumnya analisis framing digunakan untuk meneliti bagaimana media massa memberitakan isu-isu tertentu.

Analisis framing berangkat dari pemikiran bahwa berita merupakan hasil konstruksi realitas yang dilakukan oleh wartawan dan/atau redaksi media. Karena merupakan hasil konstruksi, maka berita yang hadir belum tentu 100 persen sama dengan realitas yang ada (Eriyanto, 2002). Tetapi ternyata konstruksi realitas bukan hanya monopoli dari perusahaan media, dan tidak hanya terjadi pada pemberitaan/ produk jurnalistik saja. Organisasi -baik itu yang bersifat mencari keuntungan (seperti misalnya perusahaan) atau pun nirlaba-dapat melakukan konstruksi atas realitas berdasarkankepentinganmereka.Pernyataan resmi organisasi (misalkan press release atau pernyataan resmi yang dipublikasikan di situsweb resmi organisasi) merupakan salah satu bentuk konstruksi realitas (Kriyantono, 2015).

Kemampuan framing untuk memahami konteks di mana komunikasi disampaikan dan dipahami memungkinkan framing untuk diterapkan dalam situasi komunikasi yang luas. Hal tersebut membuat teori framing dapat diterapkan dalam level komunikasi intrapersonal, interpersonal, kelompok, organisasi, antar-organisasi, dan komunikasi dengan lingkungan sosial PR berusaha untuk mempengaruhi melalui pesan-pesan yang mereka sampaikan. Melalui pesanpesan tersebut, berpeluang mengubah opini negatif menjadi opini positif (Hallahan, 1999; Sumarto, 2016).

Secara empirik, framing pun memegang peranan penting dalam penyusunan strategi PR. Framing menyediakan dasar untuk PR guna memilih tema-tema yang hendak disampaikan kepada masyarakat, sekaligus cara untuk memperkuat pesan-pesan kunci organisasi (Hallahan, 1999: 224).

Perkembangan teknologi komunikasi memudahkan dalam proses pengumpulan data untuk penelitian PR menggunakan metode analisis frmaing. Sejumlah organisasi telah memanfaatkan situsweb resmi mereka untuk mempublikasikan pernyataanpernyataan resmi berkaitan dengan isu tertentu -terutama permasalahan yang tengah menimpa organisasi.

Pernyataan-pernyataan di situsweb resmi organisasi bermanfaat bagi peneliti untuk mengetahui isi pesan organisasi secara utuh. Sebab apabila hanya menggunakan pernyataan organisasi yang dimuat di media massa, ada risiko pesan tersebut telah terdistorsi. Menurut Dewa Broto (2014: 6) media massa cenderung sudah memiliki pilihan pasar tersendiri antara tema yang akan diangkat atau sebaliknya. Artinya pemberitaan yang ada mungkin berbeda konteks dengan isi pesan resmi organisasi.

Tulisan ini bertujuan untuk memberikan gambaran bagaimana penggunaan analisis framing dalam penelitian PR, melalui contoh kasus. Ada pun model framing yang digunakan sebagai contoh dalam tulisan ini adalah model Entman dan model PanKosicki.

\section{TINJAUAN PUSTAKA}

Secara garis besar terdapat lima pendekatan dalam penelitian PR, yakni 
pendekatan sistem/teori sistem, retoris, kritis, manajemen hubungan, dan postmodern. Pendekatan yang berkaitan bagaimana pesan PRdibuatatau dikonstruksi merupakan pendekatan retoris. Pendekatan retoris didominasi oleh pemikiran Burke yang berpandangan tentang adanya proses dialektika di mana pihak-pihak yang terlibat menggunakan pertukaran simbolis untuk mencapai kesepakatan mengenai struktur kultural, tindakan, dan peristiwa. Berdasarkan pandangan Burke, Heath berpendapat perspektif retoris bermaksud menjelaskan dinamika menyangkut faktorfaktor berikut: situasi yang membutuhkan respon strategis, problem yang muncul dari sebuah sistuasi, membahas mengenai publik sasaran, pesan, sumber pesan, citra, atau opini yang berlangsung di seputar situasi tersebut (Tench \& Deflagbe, 2008: 12-16; Hallahan, 1999: 206).

Secara implisit framing memainkan peran yang tidak bisa dipisahkan dari aktivitas PR. Dengan framing, PR membantu organisasi untuk mendefinisikan realitas dengan membentuk cara pandang organisasi tentang lingkungan luar. Dengan framing, PR dapat membangun bingkai berpikir (frame of reference) tentang isu-isu tertentu yang menjadi perhatian merupakan hal yang penting dilakukan PR (Hallahan, 1999: 206207).

Framing memang jarang digunakan dalam praktek PR, namun begitu tetaplah penting. Dalam mengembangkan program, PR perlu menggunakan strategi framing yang akanmenentukanbagaimanasituasi,atribusi, pilihan, tindakan, isu, dan tanggungjawab organisasi harus disampaikan kepada publik, dengan tujuan memberikan hasil yang sesuai harapan organisasi (Hallahan, 1999: 224).

Dalam kasus Indonesia, sebagai contoh adalah pernyataan resmi PT Semen Indonesia berkaitan dengan pembangunan pabrik di kawasan Rembang, Jawa Tengah. Pembangunan tersebutditentang masyarakat dan sejumlah kelompok masyarakat, yang menilai bahwa pembangunan pabrik berpotensi merusak lingkungan. Dalam merespon hal tersebut, PT Semen Indonesia melalui pernyataan yang dipublikasikan di situsweb resmi perusahaan menyampaikan bahwa ketakutan itu tidak beralasan. Sebaliknya, mereka mengklaim keberadaan mereka justru dapat memberikan kesejahteraan bagi masyarakat sekitar. PT Semen Indonesia memperkuat klaim mereka dengan data-data mengenai kegiatankegiatan sosial mereka terhadap masyarakat Rembang. Selain itu PT Semen Indonesia juga menonjolkan informasi tentang kondisi lingkungan dan masyarakat di sekitar pabrik yang dibangun di kawasan lain di Indonesia. Selain itu PT Semen Indonesia juga menonjolkan (Febrigiasti, 2016).

Dalam kasus internasional, misalkan upaya perusahaan perminyakan BP yang berusaha "menghindari" bertanggungjawab secara penuh terhadap kejadian tumpahan minyak di kawasan perairan Amerika Serikat. BP mem-framing pernyataan resmi mereka dengan menyatakan bahwa mereka berusaha untuk mengatasi masalah yang terjadi, dan memposisikan diri mereka sebagai pihak yang berusaha menyediakan solusi. Padahal dalam pemberitaan media yang beredar, kejadian tumpahan minyak ini akibat adanya kesalahan teknis yang dilakukan oleh BP. Dari 126 siaran pers BP berkaitan dengan kasus ini, mayoritas membahas tentang peristiwa tumpahan minyak itu sendiri (74\%), dan sangat sedikit (1\%) yang membahas tentang penyebabnya. BP juga menyampaikan lebih banyak pesan mengenai strategi penyelesaian yang mereka terapkan (66\%) dibanding dengan dampak dari tumpahan minyak tersebut (Schulz, 2011).

\section{HASIL DAN PEMBAHASAN}

\section{Analisis Framing dan Model Framing}

Analisis framing pada umumnya digunakan dalam penelitian teks media. Menurut Eriyanto (2002: 10), pada dasarnya framing adalah metode untuk mengetahui bagaimana cara bercerita (story telling) media atas peristiwa, dengan melihat bagaimana peristiwa dipahami dan dibingkai oleh media. Namun begitu, organisasi juga dapat melakukan framing dalam pesan- 
pesan komunikasi yang mereka sampaikan. Pernyataan yang disampaikan oleh organisasi pun -baik itu melalui siaran pers atau website perusahaan-- juga merupakan sebuah konstruksi atas realitas. Organisasi mengemas pesan yang mereka sampaikan dengan frame tertentu bertujuan untuk mendefinisikan suatu peristiwa atau isu dan bertujuan untuk mempengaruhi opini publik sehingga tercipta citra organisasi yang positif (Kriyantono, 2015: 213, 316). Terdapat empat model framing yang populer yakni Pan \& Kosicki, Entman, Edelman, dan Gamson (Eriyanto ,2002).

Untuk tulisan ini mengambil contoh model Entman dan Pan \& Kosicki. Entman melihat framing dalam dua dimensi besar yakni seleksi isu dan penekanan atau penonjolan aspek-aspek tertentu dari sebuah isu. Cara pandang seperti itu menentukan fakta apa yang hendak diambil, bagian mana yang hendak ditonjolkan dan dihilangkan, dan hendak dibawa ke mana isi informasi tersebut. Dalam konsepsi Entman, framing pada dasarnya merujuk pada pemberian definisi, memperkirakan masalah atau sumber masalah, evaluasi dan rekomendasi dalam suatu wacana untuk menekankan kerangka berpikir tertentu terhadap peristiwa yang diwacanakan (Eriyanto, 2002: 187188). Penjelasan singkat tentang komponen framing ada di Tabel 1.

\section{Tabel 1. Komponen Framing Model Robert}

\section{N. Entman}

\begin{tabular}{|l|l|}
\hline Komponen Framing & Penjelasan \\
\hline $\begin{array}{l}\text { Pendefinisian masalah } \\
\text { (Define Problem) }\end{array}$ & $\begin{array}{l}\text { Bagaimana suatu peristiwa/ } \\
\text { isu dilihat? Sebagai apa? Atau } \\
\text { sebagai masalah apa? }\end{array}$ \\
\hline $\begin{array}{l}\text { Memperkirakan } \\
\text { masalah atau sumber } \\
\text { masalah (defining } \\
\text { causes) }\end{array}$ & $\begin{array}{l}\text { Peristiwa itu dilihat disebabkan } \\
\text { oleh apa? Apa yang dianggap } \\
\text { sebagai penyebab dari suatu } \\
\text { masalah? Siapa aktor yang } \\
\text { dianggap sebagai penyebab } \\
\text { masalah? }\end{array}$ \\
\hline $\begin{array}{l}\text { Menekankan } \\
\text { penyelesaian } \\
\text { (treatment } \\
\text { recommendation) }\end{array}$ & $\begin{array}{l}\text { Penyelesaian apa yang } \\
\text { ditawarkan untuk mengatasi } \\
\text { masalah/isu? Jalan apa yang } \\
\text { ditawarkan dan harus ditempuh } \\
\text { untuk mengatasi masalah? }\end{array}$ \\
\hline
\end{tabular}

\begin{tabular}{|l|l|}
\hline Membuat keputusan & Nilai moral apa yang disajikan \\
moral (make moral & untuk menjelaskan masalah? \\
judgement) & Nilai moral apa yang dipakai \\
& untuk melegitimasi atau \\
& mendelegitimasi r suatu \\
& tindakan? \\
\hline
\end{tabular}

Sementara dalam model framing Pan \& Kosicki terdapat empat komponen guna mengetahui level teksyaitu strukturSintaksis, struktur skrip, struktur tematik dan struktur retoris (Eriyanto, 2002: 255-266). Penjelasan secara singkat mengenai masing-masing komponen ada di Tabel 2.

\section{Tabel 2. Komponen Framing Model Pan \& Kosicki}

\begin{tabular}{|c|c|}
\hline $\begin{array}{l}\text { Komponen } \\
\text { Framing } \\
\end{array}$ & Penjelasan \\
\hline Struktur Sintaksis & $\begin{array}{l}\text { menjelaskan bagaimana cara } \\
\text { menyusun fakta. Susunan fakta } \\
\text { dilihat dari judul, pengantar } \\
\text { informasi (lead), latar informasi, } \\
\text { kutipan sumber, pernyataan, } \\
\text { penutup }\end{array}$ \\
\hline Struktur Skrip & $\begin{array}{l}\text { menjelaskan bagaimana cara } \\
\text { mengisahkan fakta. Untuk elemen } \\
\text { yang diamati adalah kelengkapan } \\
\text { berita } 5 \mathrm{~W}+1 \mathrm{H} \text {. }\end{array}$ \\
\hline ematik & $\begin{array}{l}\text { menjelaskan bagaimana cara } \\
\text { menuliskan fakta. beberapa elemen } \\
\text { yang dapat diamati dari perangkat } \\
\text { tematik ini, di antaranya detil, } \\
\text { bentuk kalimat, hubungan antar } \\
\text { kalimat, dan kata ganti }\end{array}$ \\
\hline Struktur retoris & $\begin{array}{l}\text { digunakan untuk membuat citra, } \\
\text { meningkatkan penonjolan pada } \\
\text { sisi tertentu dan meningkatkan } \\
\text { gambaran yang diinginkan dari } \\
\text { suatu tulisan. Struktur retoris dari } \\
\text { wacana berita juga menunjukkan } \\
\text { kecenderungan bahwa apa yang } \\
\text { disampaikan tersebut adalah suatu } \\
\text { kebenaran. Ada beberapa elemen } \\
\text { struktur retoris yang dipakai } \\
\text { misalkan pemilihan dan pemakaian } \\
\text { kata - kata tertentu untuk menandai } \\
\text { atau menggambarkan peristiwa }\end{array}$ \\
\hline
\end{tabular}

Dalam tujuh konsep PR menurut Hallahan (1999), cara PT Semen Indonesia membingkai pesan adalah pada frame atribusi dan tanggungjawab. Frame atribusi merupakan bagaimana cara organisasi memposisikan diri. Sementara frame 
tanggungjawab merupakan cara organisasi menunjukkan bertanggungjawab sesuai dengan kapasitas mereka.

Define Problem. PT Semen Indonesia menyadari bahwa operasional perusahaan mereka memiliki risiko terhadap lingkungan hidup. Oleh karenanya PT Semen Indonesia sudah menyiapkan teknologi yang berguna untuk meminimalkan dampak negatif tersebut. Bahkan khusus untuk pabrik di Rembang, PT Semen Indonesia mempersiapkan teknologi yang lebih baik daripada pabrik PT Semen Indonesia di kota lain. Guna memperkuat klaim tersebut, PT Semen Indonesia mengatakan bahwa pembangunan PT Semen Indonesia telah melalui perencanaan yang matang. Pernyataan terdapat pada kalimat-kalimat berikut. Bagian yang dicetak tebal (oleh penulis) merupakan kata-kata kunci dalam kalimat tersebut:

Seluruh pabrik Semen Indonesia memiliki aplikasi teknologi yang ramah lingkungan. Sehingga dipastikan kegiatan operasionalnya akan sangat ramah lingkungan. Teknologi dan peralatan yang lebih canggih akan diaplikasikan di Pabrik Rembang, sehingga kualitas lingkungan akan lebih baik dari pabrik Semen Indonesia yang lain. "Tidak ada yang perlu dikhawatirkan dalam kegiatan proyek pembangunan maupun pasca proyek di Rembang. Semuanya sudah melalui kajian yang mendalam oleh para ahli," tegas Prasetyo Utomo

Defining Causes. PT Semen Indonesia menganggap bahwa penolakan pabrik di Rembang akibat masyarakat belum paham tentang bagaimana sebenarnya operasional PT Semen Indonesia. Itu sebabnya PT Semen Indonesia terbuka bagi masyarakat yang ingin mengetahui mengenai hal tersbut. Dalam pernyataan resminya, PT Semen Indonesia juga memberikan penonjolan kepada jumlah, domisili, dan latar belakang warga Rembang yang datang melakukan kunjungan ke pabrik di Tuban. Penonjolan tersebut bermaksud meng-counter pihakpihak yang tidak mengetahui bagaimana operasional PT Semen Indonesia, tetapi langsung berdemonstrasi dan menyatakan keberatan. Penonjolan juga dilakukan pada informasi bahwa yang menerima warga adalah pejabat setingkat direktur, guna menunjukkan keseriusan PT Semen Indonesia dalam menerima kunjungan wrga. Pernyataan terdapat pada kalimat-kalimat berikut. Bagian yang dicetak tebal (oleh penulis) merupakan kata-kata kunci dalam kalimat tersebut:

Sebanyak 200 warga yang terdiri beberapa desa di Rembang dan Blora (Desa Suntri, Dowan, Bulu, Mantingan, Kadiwono Kec Gunem serta Desa Bulu, Ngampel Kec Blora dan pelajar kejar paket A, B dan C) mengunjungi Pabrik PT Semen Indonesia (Persero) Tbk di Tuban Jawa Timur, kedatangan mereka untuk mengetahui secara langsung operasional perusahaan serta pengelolaan lingkungan.

Kunjungan diterima oleh Direktur Produksi Semen Gresik Prasetyo Utomo di Ruang Auditorium Pabrik Tuban. Direktur Produksi PT Semen Gresik Prasetyo Utomo mengatakan "Kami selalu terbuka kepada seluruh masyarakat yang ingin mengunjungi Pabrik kami, dengan harapan masyarakat mengetahui bagaimana proses pembuatan semen dan keberadaanya sangat bermanfaat bagi warga sekitar".

Warga juga melihat langsung bekas galian tanah liat yang sekarang menjadi waduk. Waduktersebutbisamencukupi kebutuhan air warga di dua desa yaitu Telogowaru dan Temandang.

Treatment Recommendation. PT Semen Indonesia menawarkan beberapa penyelesaian masalah dalam hal menyatakan standar operasional secara umum (diterapkan untuk seluruh pabrik) atau khusus di Rembang saja. Misalkan penanaman kembali paksa tambang sudah tidak beroperasi lagi, penggunaan bahan bakar alternatif yang amah lingkungan sekaligus memberikan manfaat ekonomi bagi warga, serta prosedur dalam Analisis Mengenai Dampak 
Lingkungan (AMDAL) yang disebut "tidak mudah", sebelum dapat memperoleh izin operasi. Pernyataan terdapat pada kalimatkalimat berikut. Bagian yang dicetak tebal (oleh penulis) merupakan kata-kata kunci dalam kalimat tersebut:

selama ini masyarakat berfikir bahwa penambangan yang dilakukan perusahaan akan merusak lingkungan dan tidak di reklamasi, namun tidak terjadi pada PT Semen Indonesia (Persero) Tbk, pasca tambang akan dilakukan pemulihan melalui penanaman kembali atau vegetasi, adapunjenispohonyangditanamadalah tanaman pelindung dan produktif, sehingga secara tidak langsung bisa melindungi tanah, mampu menyerap air serta bermanfaat bagi masyarakat sekitar

Semen Indonesia telah menerapkan konservasienergidenganmenggunakan bahan bakar alternatif, misalnya dalam proses pembakaran kita menggunakan batubara namun sekarang kita menggunakan bahan bakar alternatif berupa sekam padi dari hasil panen warga sekitar, dengan begitu sekam padi hasil panen masyarakat yang tadinya terbuang dapat dimanfaatkan, sehingga masayarakatjuga memperoleh keuntungan secara ekonomi.

Prasetyo Utomo juga menjelaskan bahwa pembangunan pabrik semen di Rembang, Jawa Tengah nanti juga akan sangat ramah lingkungan. Bahkan kualitas keterjagaan lingkungan akan lebih baik dari pabrik perseroan yang ada di Tuban, Jawa Timur. Sebelum membangun pabrik persyaratan yang harus dipenuhi adalah adanya Analisis Dampak Lingkungan (AMDAL). Dan proses pengajuannya pun tidak sederhana. Harus melalui berbagai kajian ilmiah dari para ahli.

Moral judgement. Dalam pernyataannya, PT Semen Indonesia menonjolkan mengenai manfaat keberadaan pabrik bagi masyarakat dan komitmen PT Semen Indonesia terhadap lingkungan hidup sudah berlangsung sejak lama. Komitmen tersebut merupakan bagian dari nilai-nilai perusahaan yang dianut PT Semen Indonesia. Selain itu PT Semen Indonesia juga menegaskan bahwa keberadaan mereka tidak akan merugikan masyarakat. Dengan penonjolan ini, maka PT Semen Indonesia bermaksud untuk mengcounter anggapan-anggapan negatif tentang mereka. Pernyataan terdapat pada kalimatkalimat berikut. Bagian yang dicetak tebal (oleh penulis) merupakan kata-kata kunci dalam kalimat tersebut:

Dalam kegiatanoperasionalnya, seluruh pabrik Semen Indonesia senantiasa mengedepankan keseimbangan dan keselarasan alam. Semua sudah dikaji sehingga setiap kegiatan sudah terukur dan terkendali. Jadi tidak ada yang perlu ditakutkan dalam kegiatan operasional kami. Terbukti Setelah Pabrik Semen Indonesia beroperasi selama 20 tahun (1994-2014) kebutuhan air untuk lahan pertanian di sekitar pabrik sangat melimpah, itu dikarenakan sekarang ada lima embung (waduk) yang bisa difungsikan oleh masyarakat.

sebelum ada pabrik petani di sini panen hanya sekali dalam setahun karena sistem pertanian tadah hujan, sekarang petani disekitar pabrik bisa panen sebanyak tiga kali dalam setahun tanpa khawatir kekurangan air, selain pemanfaatan waduk sebagai pengairan, sebagian masyarakat juga memanfaatkan untuk budidaya ikan dengan sistem keramba.

Rangkuman mengenai framing dari pernyataan PT Semen Indonesia berjudul "200 Warga Rembang Kunjungi Pabrik Semen Indonesia di Tuban. Melihat Manfaat Pabrik Bagi Masyarakat Sekitar" dapat dilihat di tabel 3. 
Tabel 3. Framing Pernyataan Resmi PT Semen Indonesia

\begin{tabular}{|l|l|}
\hline Komponen Framing & Penjelasan \\
\hline $\begin{array}{l}\text { Pendefinisian } \\
\text { masalah (Define }\end{array}$ & $\begin{array}{l}\text { PT Semen Indonesia menyadari } \\
\text { bahwa operasional perusahaan } \\
\text { mereka bisa menimbulkan } \\
\text { dampaknegative bagi lingkungan } \\
\text { hidup. PT Semen Indonesia } \\
\text { telah menyiapkan strategi untuk } \\
\text { mengatasinya }\end{array}$ \\
\hline $\begin{array}{l}\text { Memperkirakan } \\
\text { masalah atau sumber } \\
\text { masalah (defining } \\
\text { causes) }\end{array}$ & $\begin{array}{l}\text { Masyarakat belum paham } \\
\text { tentang bagaimana operasional } \\
\text { PT Semen Indonesia, sehingga } \\
\text { masyarakat menganggap } \\
\text { PT Semen Indonesia tidak } \\
\text { bertanggungjawab terhadap } \\
\text { lingkungan hidup }\end{array}$ \\
\hline $\begin{array}{l}\text { Menekankan } \\
\text { penyelesaian } \\
\text { (treatment } \\
\text { recommendation) }\end{array}$ & $\begin{array}{l}\text { PTSemenIndonesiamemaparkan } \\
\text { sejumlah program yang berhasil } \\
\text { untuk meminimalkan kerusakan } \\
\text { lingkungan. Program tersebut } \\
\text { mulai dari standar kerja } \\
\text { operasional hingga teknologi } \\
\text { yang dimliki. }\end{array}$ \\
\hline $\begin{array}{l}\text { Membuat keputusan } \\
\text { moral (make moral } \\
\text { judgement) }\end{array}$ & $\begin{array}{l}\text { PTSemenIndonesiamenonjolkan } \\
\text { mengenai manfaat keberadaan } \\
\text { pabrik bagi masyarakat dan } \\
\text { komitmen PT Semen Indonesia } \\
\text { terhadap linkungan hidup sudah } \\
\text { berlangsung sejak lama. }\end{array}$ \\
\hline
\end{tabular}

\section{Contoh Penerapan Analisis Framing Model Pan \& Kosicki dalam Analisis Pernyataan Resmi Perusahaan}

Di bagian ini, penulis mengambil contoh pernyataan resmi Persatuan Sepakbola Seluruh Indonesia berkaitan dengan tuntutan agar federasi sepakbola Indonesia itu membuka laporan keuangannya kepada publik ${ }^{1}$. Pernyataan yang dipilih berjudul

1 Berikut deskripsi singkat mengenai kasus yang terjadi. Pada tahun 2014, kelompok supporter sepakbola Indonesia yang tergabung dalam Forum Diskusi Suporer Indonesia (FDSI) meminta PSSI untuk transparan dalam perihal keuangan, berkaitan dengan nilai kontrak dengan pemegang hak siar, sponsorship, perolehan dari penjualan tiket pertandingan tim nasional Indonesia, dan kerjasama dengan apparel atau penyedia kostum. Pasalnya selama ini keuangan PSSI dinilai tidak transparan dan diduga ada penyelewengan dana. FDSI dua kali melayangkan surat tuntutan transparansi kepada PSSI, namun tidak memperoleh respon positif. FDSI kemudian membawa kasus ini ke Komisi Informasi Pusat, lembaga yang bertugas mengurusi keterbukaan informasi di Indonesia. Setelah melalui serangkaian
"Rasionalitas Hukum dan Transparansi Pengelolaan PSSI" yang dipublikasikan di situsweb resmi PSSI (www.pssi.org, tanggal publikasi: 12 Desember 2014; tanggal akses: 9 April 2016). Pernyataan ini merupakan penjelasan dari Direktur Bidang Hukum PSSI, Aristo Pangaribuan, mengenai respon PSSI terhadap tuntutan untuk membuka informasi.

Struktur sintaksis melihat pada penyusunan atau urut-urutan fakta seperti judul, latar belakang peristiwa, lead (alenia pembuka) dan penutup. Pada judul PSSI menyampaikan "Rasionalitas Hukum dan Transparansi Keuangan PSSI”. Penekanan terletak pada frasa "rasionalitas hukum", di mana PSSI berusaha untuk menjelaskan bahwa tuntutan untuk transparansi keuangan harus dipahami lebih mendalam sesuai dengan hukum yang berlaku. Latar informasi yang digunakan oleh PSSI adalah tuduhan bahwa lembaga tersebut tidak transparan dalam keuangan, menimbulkan banyak asumsi negatif. Negara (melalui lembaga Komisi Informasi Pusat/KIP) memerintahkan PSSI untuk transparan dalam keuangan. PSSI menolak karena secara hukum memang PSSI tidak punya kewajiban untuk tunduk sepenuhnya terhadap negara. Guna memperkuat argumennya, PSSI menonjolkan argument yang mengkritik Undang-undang Keterlibatan Informasi Publik dan UU lain yang digunakan sebagai dasar hukum untuk menuntut PSSI transparan. Bagian yang dicetak tebal (oleh penulis) merupakan kata-kata kunci dalam kalimat tersebut

Sebelum masuk kepada perdebatan mengenai transparansi, haruslah terlebih dahulu melihat struktur hubungan hukum yang tercipta antara PSSI, publik dan pemerintah Indonesia sehingga kita dapat melihat duduk persoalannya secara jernih. Hubungan hukum ini tidak dapat dijelaskan

persidangan, pada Desember 2014 Komisi Informasi Pusat memutuskan bahwa PSSI merupakan badan public non-pemerintah sehingga wajib melakukan keterbukaan informasi kepada publik, sebagaimana diatur dalam Undang-undang No.14/2008 tentang Keterbukaan Informasi Publik. 
oleh putusan KIP maupun UndangUndang No. 3 tahun 2005 mengenai Sistem Keolahragaan Nasional (UU SKN) sehingga menimbulkan banyak kerancuan hukum dalam pengelolaan olahraga di Indonesia pada umumnya.

Struktur Skrip melihat pada cara bagaimana mengisahkan fakta. Dalam analisis framing untuk jurnalistik, komponen yang diamati adalah ${ }_{5} \mathrm{~W}$ (What, Why, Where, When, Who, Why) dan $1 \mathrm{H}$ (How). PSSI menjadikan faktor why, untuk menjelaskan mengapa mereka bertahan dengan sikapnya yang menolak untuk menuruti keputusan KIP. Penjelasan tersebut menggunakan sejumlah asas hukum dan dasar hukum yang menilai bahwa keputusan KIP dan tuntutan transparansi belum memiliki pijakan hukum yang kuat.

Stuktur Tematik di antaranya detil, bentuk kalimat, hubungan antar kalimat, dan kata ganti. Dalam penyusunan uruturutan pesan, pernyataaan resmi tersebut memuat pokok pikiran sebagai berikut: (1) Kritik terhadap UU KIP dan UU Sistem Keolahragaan Nasional dengan memaparkan kelemahan-kelemahan, (2) Hubungan antara pemerintah dengan PSSI secara hukum, (3) PSSI menghargai suara suporter, tetapi asalkan memiliki dasar yang kuat, (4) PSSI mengharapkan peran serta pemerintah guna menyusun hukum yang jelas, tujuannya agar mewujudkan sistem pengelolaan sepakbola yang baik. Contohnya adalah di bagian akhir tulisan,di mana PSSI menyatakan menghargai tuntutan dari suporter, PSSI tidak alergi terhadap keterbukaan, asalkan diiringi dengan rasionalitas hukum yang jelas. Namun begitu ada sejumlah kata-kata yang hendak menonjolkan bahwa tuntutan keterbukaan tidak datang dari semua suporter.

Selan itu PSSI juga menyentil pemerintah yang dituding kurang mampu dalam merumuskan aturan yang jelas, sehingga kebijakan PSSI sering disalahpahami. Contohnya adalah kalimat di bawah ini. Bagian yang dicetak tebal (oleh penulis) merupakan kata-kata kunci dalam kalimat tersebut

PSSI tentunya menghargai suara sebagian suporter yang menuntut transparansi terhadap keuangan PSSI, karena organisasi sepakbola tanpa suporter tidak akan bisa berjalan. Suporter adalah salah satu stakeholder PSSI yang paling penting. Keterbukaan bagi PSSI bukanlah barang haram. Hanya saja, persoalan transparansi haruslah diikuti dengan rasionalitas hukum yang jelas. Pemerintah perlu menetapkan suatu mekanisme hubungan hukum yang jelas sehingga tidak terjadi kerancuan hukum dalam pengelolaan olahraga di Indonesia. Dengan dasar hukum yang jelas, niscaya tranparansi dan akuntabilitas PSSI akan berjalan dan akhirnya citacita membangun sebuah "peradaban sepakbola” akan terwujud.

Struktur Retoris digunakan untuk menunjukkan kecenderungan bahwa apa yang disampaikan tersebut adalah suatu kebenaran. Struktur retorisdalam pernyataan PSSI menggunakan daftar undang-undang, aturan hukum baik itu yang mendukung PSSI atau pun yang menunjukkan kelemahan dari keputusan yang meminta PSSI untuk transparan. Misalnya ada dalam kalimat berikut. Bagian yang dicetak tebal (oleh penulis) merupakan kata-kata kunci dalam kalimat tersebut:

Akta Pengesahan PSSI tertanggal 2 Februari 1953 berdasarkan Buku Undang-Undang no. 276 (Staatsblad), Melalui UU SKN pada pasal 1 poin 25 Pemerintah jelas mensyaratkan bahwa indukorganisasiolahragaharus menjadi anggota federasi cabang olahraga internasional yang bersangkutan, dalam hal ini FIFA. di PP 45/2013 tentang Tata Cara Pelaksanaan APBN. Pengguna Anggaran (PA) yang memiliki tanggung jawab untuk bertanggung jawab terhadap penggunaan anggaran, dalam hal ini adalah Menteri Pemuda dan Olahraga (Menpora) sebagaimana yang ada di dalam Pasal 4 PP tersebut dan UU SKN. Sedangkan untuk dana luar negeri, PP no.10/2011 menyatakan yang disebutkan sebagai bantuan luar 
negeri adalah bantuan yang kepada pemerintah yang kemudian harus dicatatkan dalam laporan keuangan pemerintah

Dari 7 kerangka hukum: UU SKN dan peraturan pelaksanaannya, Kitab Undang-Undang Hukum Perdata, Peraturan Menteri Hukum dan HAM no 6/2014 mengenai pengesahan perkumpulan,UUno. 17/2003 mengenai Keuangan Negara, UU no 1 tahun 2004 mengenai Perbendaharaan Negara, Peraturan Pemerintah no. 45/2013 mengenai Tata Cara Pelaksanaan APBN dan Peraturan Pemerintah no 10/2011 mengenai Penerimaan Hibah dari Luar Negeri. Karena "kunci" dari badan publik adalah menjalankan tugas-tugas pemerintahan serta mendapatkan dana dari negara, baik yang berasal dari APBN maupun APBD

Secara umum, analisis framing terhadap menggunakan model Pan \& Kosicki dapat dilihat di Tabel 4

Tabel 4. Komponen Framing Model Pan \& Kosicki

\begin{tabular}{|l|l|}
\hline $\begin{array}{l}\text { Komponen } \\
\text { Framing }\end{array}$ & Penjelasan \\
\hline Struktur Sintaksis & $\begin{array}{l}\text { Sejak awal tulisan PSSI langsung } \\
\text { menyoroti pada pembahasan bahwa } \\
\text { keputusan PSSI untuk transparan } \\
\text { tidak memiliki dasar hukum yang } \\
\text { kuat. Bahkan dasar hukum yang } \\
\text { digunakan patut dipertanyakan, } \\
\text { karena masih bisa diperdebatkan }\end{array}$ \\
\hline Struktur Skrip & $\begin{array}{l}\text { Menekankan pada unsur WHY, } \\
\text { untuk menjelaskan mengapa PSSI } \\
\text { tidakmaumenuruti perintah Negara } \\
\text { (keputusan Komisi Informasi } \\
\text { Pusat agar PSSI transparan soal } \\
\text { keuangan) }\end{array}$ \\
\hline Struktur tematik & $\begin{array}{l}\text { (1) Kritik terhadap UU KIP dan } \\
\text { UU Sistem Keolahragaan Nasional } \\
\text { dengan memaparkan kelemahan- } \\
\text { kelemahan, (2) Hubungan antara } \\
\text { pemerintah dengan PSSI secara } \\
\text { hukum, (3) PSSI menghargai } \\
\text { suara suporter, tetapi asalkan } \\
\text { memiliki dasar yang kuat, (4) } \\
\text { PSSI mengharapkan peran serta } \\
\text { pemerintah guna menyusun } \\
\text { hukum yang jelas, tujuannya agar } \\
\text { mewujudkan sistem pengelolaan } \\
\text { sepakbola yang baik }\end{array}$ \\
\hline
\end{tabular}

\begin{tabular}{|l|l|}
\hline Struktur retoris & menggunakan daftar undang- \\
& undang, aturan hukum baik itu \\
yang mendukung PSSI atau pun \\
yang menunjukkan kelemahan \\
dari keputusan yang meminta PSSI \\
untuk transparan. \\
\hline
\end{tabular}

\section{SIMPULAN}

Analisis framing memang masih jarang digunakan dalam penelitian PR. Hal tersebut karena analisis framing lebih familiar dengan penelitian di bidang jurnalistik, khususnya analisis isi pemberitaan. Padahal apabila berangkat dari salah satu kata kunci dalam framing, yakni konstruksi atas realitas, maka analisis framing bisa saja digunakan dalam penelitian PR. Yang menjadi objek bukan lagi berita (produk media/produk jurnalistik), namun pernyataan-pernyataan resmi dari organisasi. Sebab, organisasi juga dapat melakukan konstruksi realitas.

Secara akademis, manfaat pertama analisis framing dalam penelitian PR berguna untuk mengetahui bagaimana organisasi memposisikan diri dalam sebuah situasi tertentu. Misalkan dalam situasi krisis, bagaimanaorganisasi tersebutmemposisikan dirinya: apakah sebagai korban, apakah bersedia bertanggungjawab namun secara terbatas, bersedia bertanggungjawab sepenuhnya, menyalahkan pihak lain, membantah, atau yang lain. Manfaat kedua adalah untuk mengevaluasi apakah pesan yang disampaikan oleh organisasi sudah sesuai atau belum dengan agenda setting media dan/atau opini publik.

Analisis framing dalam penelitian PR sebaiknya tidak sekadar berhenti di analisis teks terhadap pernyataan resmi organisasi. Agar data penelitian semakin kaya, perlu data tambahan dari sumber yang lain. Misalkan setelah mengetahui bagaimana organisasi memposisikan diri dalam situasi, peneliti kemudian dapat melakukan wawancara dengan pihak PR/humas dari organisasi tersebut untuk menanyakan bagaimana kebijakan dalam penyusunan pernyataan resmi, faktor-faktor apa yang menjadi pertimbangan dalam menyusun konten di pernyataan resmi, dan sebagainya. 
Penelitian lain yang bisa dilakukan untuk "mendampingi" analisis framing dalam penelitian PR adalah melakukan analisis framing pemberitaanmediaberkaitandengan isu yang sama. Penelitian Schulz, et.al (2011) misalkan, membandingkan bagaimana frame pernyataan resmi dari perusahaan minyak BP dengan pemberitaan di surat kabar di Amerika Serikat dan Inggris, berkaitan dengan krisis tumpahan minyak di perairan kawasan Amerika Serikat. Penelitian tersebut berguna untuk mengetahui bagaimana agenda setting media.

Sedangkan untuk mengetahui opini publik, maka penelitian bisa dilanjutkan dengan melakukan survey terhadap opini masyarakat tentang sebuah isu. Pertanyaanpertanyaandalamsurveydisusunberdasarkan analisis framing terhadap pernyataan resmi organisasi.

Untuk manfaat praktis, PR organisasi perlu mengetahui bagaimana opini publik dan agenda setting media sebelum melakukan frame terhadap pernyataan resmi. Frame penting bagi pesan organisasi karena pesan dapat mengubah opini yang selama ini terbentuk terlebih opini yang negatif. Untuk itu, dalam menyusun pesan praktisi PR organisasi perlu memiliki kemampuan membingkai pesan yaitu strategi dalam memilih, menonjolkan dan menghubungkan fakta ke dalam bentuk pesan agar lebih bermakna, lebih menarik, lebih berarti atau lebih diingat, dengan kata-kata yang mudah dipahami (Sumarto, 2016: 65, 69)

Hal yang perlu diingat adalah ada kalanya "persepsi bisa menjadi fakta" (Kriyantono, 2012: 199), maka sebaiknya organisasi membingkai pesan yang tidak bertentangan dengan opini publik dan/atau agenda setting media. Pasalnya, apabila organisasi memberikan penjelasan dengan frame berusaha membantah, bertahan dalam sikapnya, terlebih sampai menyalahkan pihak lain, hal tersebut malah akan kontraproduktif. Cara seperti itu membuat citra organisasi menjadi tidak baik di mata masyarakat, sehingga masyarakat akan sulit percaya lagi dengan apa yang dikatakan organisasisekalipun hal-hal yang disampaikan itu memilik dasar yang kuat. Sikap seperti itu membuat kredibilitas organisasi menjadi turun. Padahal, menurut Sumarto (2016 : 70), organisasi perlu memiliki kredibilitas yang tinggi di mata public agar komunikasi berjalan dengan lancar.

Contohnya ketika PSSI tengah banjir kecaman karena tidak bersedia untuk membuka laporan keuangan mereka kepada public, padahal Negara (melalui Komisi Informasi Pusat) telah memerintahkan PSSI untuk melakukannya. PSSI melalui pernyataan di situsweb menyatakant bahwa mereka tidak punya kewajiban untuk membuka informasi dan menuruti ketetapan KIP. Guna memperkuat argumennya, PSSI menggunakan dasar hukum mengenai posisi mereka sebagai organisasi yang bukan badan publik, sekaligus mengkritisi aturan yang berlaku di Indonesia.

Secara hukum, sifat organisasi PSSI memang merupakan mitra pemerintah, bukan bawahan dari pemerintah (Pandjaitan, 2011). Meski secara hukum argument PSSI cukup kuat, namun ketika PSSI memutuskan untuk ngotot bertahan dengan sikapnya (melalui pernyataan-pernyataannya), maka hal tersebut dapat membuat orang menjadi tidak simpatik pada PSSI. Organisasi perlu memperhatikan opini publik karena dapat juga berimbas kepada agenda setting media. Dalam penelitiannya, Prayoga (2016) menemukan bahwa dalam beberapa situasi, redaksi mediaakancenderung memberitakan mengikuti seperti apa opini publik yang beredar.

Setelah mengetahui bagaimana opini publik dan/atau agenda setting media, maka PR organisasi juga perlu mengetahui tentang komponen-komponen framing, sehingga berguna untuk menentukan isu-isu apa saja yang hendak ditonjolkan dan bagaimana bahasa yang tepat untuk menyampaikannya. 


\section{DAFTAR PUSTAKA}

Dewa Broto, G.S. 2014. The PR: Tantangan Public Relations pada Era Keterbukaan. Jakarta : PT Gramedia Pustaka Utama

Eriyanto. 2002. Analisis Framing: Konstruksi, Ideologi dan Politik Media. Yogyakarta: LkiS

Febrigiasti, A.K. 2016. "Strategi Manajemen Krisis PT Semen Indonesia (PERSERO) Tbk: Studi Kasus pada Proyek Pembangunan Pabrik di Rembang”. Skripsi (tidak dipublikasikan). Program Studi Ilmu Komunikasi, Fakultas Psikologi dan Ilmu Sosial Budaya, Universitas Islam Indonesia, Yogyakarta

Hallahan, K. 1999. "Seven Models of Framing: Implications for Public Relations" dalam Journal of Public Relations Research 11 (3): 205-242. URL: http://www4.ncsu. edu/ amgutsch/Hallahan.pdf, diakses 10 Agustus 2016

Kriyantono, R. 2012. Public Relations \& Crisis Management: Pendekatan Critical Public Relations, Etnografi Kritis $\mathcal{E}$ Kualitatif. Jakarta : Kencana Prenada Media Group

Kriyantono, R. 2015. Teori Public Relations Perspektif Barat dan Lokal: Aplikasi Penelitian dan Praktik. Jakarta : Kencana Prenada Media Group

Pandjaitan, H.IP. 2011. Kedaulatan Negara vs Kedaulatan FIFA: Bagaimana Mendudukkan Masalah PSSI dan Negara (Pemerintah Indonesia). Jakarta : PT Gramedia Pustaka Utama

Prayoga, R.G. 2016. “Kontroversi Penghentian Kompetisi ISL 2015 dalam Bingkai Berita Harian Olahraga Nasional”. Skripsi (tidak dipublikasikan). Program Studi Ilmu Komunikasi, Fakultas Psikologi dan Ilmu Sosial Budaya, Universitas Islam Indonesia, Yogyakarta

Schultz, F., J. Kleinnijenhuis, D. Oegema, S. Utz, \& W.van Atteveldt. 2011. Strategic framing in the BP crisis: A semantic network analysis of associative frames. Public Relations Review (2011). Article in Press. doi:10.1016/j.pubrev.2011.08.003. URL: https://www.researchgate.net/ publication/251582747_Strategic_ framing_in_the_B P_crisis_A semantic_network_analysis_of associative_frames, diakses 10 Agustus 2016

Sumarto, R.H. 2016. "Komunikasi dalam Kegiatan Public Relations", dalamJurnal Informasi Vol 46, No 1, hal.63-72 (ISSN Online 2502-3837). URL: http://journal. uny.ac.id/index.php/informasi/article/ view/9650/7699, diakses 23 Agustus 2016

Tench, R. \& D. Deflagbe. 2008. “Towards a Global Curriculum: A summary of literature concerning public relations education, professionalism and globalization". Report for the Global Alliance of Public Relations and Communication Management, Leeds Metropolitan University, UK. http:// www.globalalliancepr.org/website/ page/global-curriculum, diakses 1 Februari 2013

\section{Pernyataan Resmi Organisasi}

“2oo Warga Rembang Kunjungi Pabrik Semen Indonesia di Tuban, Melihat Manfaat Pabrik Bagi Masyarakat Sekitar". Website resmi PT Semen Indonesia (URL: http://semenindonesia.com/ page/read/-warga-rembang-kunjungipabrik-semen-indonesia-di-tubanmelihat-manfaat-pabrik-bagimasyarakat-sekitar-2745, tanggal akses: 10 Agustus 2016)

Rasionalitas Hukum dan Transparansi Pengelolaan PSSI. Website resmi PSSI (URL: http://pssi.org/in/read/ PSSI / Rasionalitas-Hukum-danTransparansi-Pengelolaan-PSSI-6180, tanggal akses : 9 April 2016) 
INFORMASI Kajian Ilmu Komunikasi Volume 46. Nomor 2. Desember 2016 